Review

\title{
Regulation of Intestinal Glucose Absorption by Ion Channels and Transporters
}

\author{
Lihong Chen ${ }^{1}$, Biguang Tuo ${ }^{1, *}$ and Hui Dong ${ }^{1,2, *}$
}

Received: 16 November 2015; Accepted: 6 January 2016; Published: 14 January 2016

1 Department of Gastroenterology, Affiliated Hospital, Zunyi Medical College, and Digestive Disease Institute of Guizhou Province, Zunyi 563003, China; 18786841557@163.com

2 Department of Gastroenterology, Xinqiao Hospital, Third Military Medical University, Chongqing 400037, China

* Correspondence: tuobiguang@aliyun.com (B.T.); h2dong@uscd.edu (H.D.); Tel.: +86-852-8609205 (B.T.); +86-23-6876-3171 (H.D.)

\begin{abstract}
The absorption of glucose is electrogenic in the small intestinal epithelium. The major route for the transport of dietary glucose from intestinal lumen into enterocytes is the $\mathrm{Na}^{+} /$glucose cotransporter (SGLT1), although glucose transporter type 2 (GLUT2) may also play a role. The membrane potential of small intestinal epithelial cells (IEC) is important to regulate the activity of SGLT1. The maintenance of membrane potential mainly depends on the activities of cation channels and transporters. While the importance of SGLT1 in glucose absorption has been systemically studied in detail, little is currently known about the regulation of SGLT1 activity by cation channels and transporters. A growing line of evidence suggests that cytosolic calcium $\left(\left[\mathrm{Ca}^{2+}\right]_{\mathrm{cyt}}\right)$ can regulate the absorption of glucose by adjusting GLUT2 and SGLT1. Moreover, the absorption of glucose and homeostasis of $\mathrm{Ca}^{2+}$ in IEC are regulated by cation channels and transporters, such as $\mathrm{Ca}^{2+}$ channels, $\mathrm{K}^{+}$channels, $\mathrm{Na}^{+} / \mathrm{Ca}^{2+}$ exchangers, and $\mathrm{Na}^{+} / \mathrm{H}^{+}$exchangers. In this review, we consider the involvement of these cation channels and transporters in the regulation of glucose uptake in the small intestine. Modulation of them may be a potential strategy for the management of obesity and diabetes.
\end{abstract}

Keywords: glucose uptake; $\mathrm{Na}^{+}$/glucose cotransporter; $\mathrm{Ca}^{2+}$ channels; $\mathrm{K}^{+}$channels; $\mathrm{Na}^{+} / \mathrm{Ca}^{2+}$ exchanger; $\mathrm{Na}^{+} / \mathrm{H}^{+}$exchanger; glucose transporter type 2

\section{Introduction}

Obesity or overweight is associated with a high risk of many diseases, such as ischemic heart disease, diabetes mellitus, hypertension, hyperlipidemia and cancers. Obesity and its related metabolic disorders are a global pandemic and the obese group has shorter life expectancy than normal of about 10 to 20 years. In the United States, around 71\% of the population is either overweight or obese [1]. Therefore, healthy weight loss is a serious worldwide problem that urgently needs to be solved. At present, the major ways to prevent/treat obesity are the medications that mainly suppress appetite [2] (such as fluorine, benzedrine and sibutramine) or surgical procedures (such as gastric bypass surgery and gastrointestinal electrical stimulation, etc.). However, these ways will also disturb the absorption of other important nutrients, including vitamins, folic acid and so on, and finally may influence the balance of nutrients in the human body. Therefore, with a quick increase in the populations of overweight and obesity worldwide, it is urgent to investigate the detailed regulatory mechanisms of special nutrient absorption in order to find better strategies for fighting obesity.

Although obesity is a metabolic disease induced by multiple factors, it mainly results from an imbalance between energy intake and expenditure. Energy intake depends on the amount of nutrients absorbed by the brush border membrane of small intestinal epithelial cells (IEC) and on 
the amount of nutrients transported by mesenteric capillaries and lacteals. It has been generally accepted that excessive intake of glucose is one of the major sources for accumulating fat, and, therefore, selective inhibition of excessive glucose intake may disturb the absorption of other important nutrients less. Robert K. Crane originally described the cellular model of absorption of $\mathrm{Na}^{+}$and glucose by a "co-transport process" in 1960 [3]. When the hypothesis of intestinal $\mathrm{Na}^{+} /$glucose co-transporter-mediated glucose absorption was proposed, the mechanisms of glucose absorption became a hot field of research. Afterwards, the SGLT1 gene was cloned on IEC and then most scholars focused their research on this transporter. Valentin Gorboulev and coworkers found that SGLT1 ${ }^{-/-}$ mice lost their body weight [4], confirming its important role in the control of glucose absorption and, thus, body weight.

SGLT1 activity could be regulated by various factors, such as protein kinases [5]. Alexander used Ussing chamber technology to show that Insulin-like Growth Factors (IGF) affect jejunal glucose transport by PI3-kinase to stimulate $\mathrm{Na}^{+}-\mathrm{K}^{+}$-ATP-ase activity in enterocytes and enhanced $\mathrm{Na}^{+}$-couple glucose absorption [6]. Nevertheless, Casselbrant proposed that angiotension II combined with the angiotensin type 1 receptor (AT1R) or angiotensin type 2 receptor (AT2R), exerting the opposite action in mediating jejunal glucose $/ \mathrm{Na}^{+}$absorption [7]. Since the absorption of glucose is electrogenic [8] and mainly depends on the $\mathrm{Na}^{+}$gradient across the epithelium, the changes in membrane potential of IEC can influence glucose absorption. Membrane potential is mainly controlled by activity of voltage-gated $\mathrm{K}^{+}$channels $(\mathrm{Kv})$. Decreasing the activity of $\mathrm{Kv}$ channels by applying $\mathrm{Kv}$ channel inhibitors results in membrane depolarization $[9,10]$. It is obvious that membrane depolarization or hyperpolarization can regulate the activity of SGLT1 on IEC. In addition to this aspect, as an important intracellular secondary messenger, $\mathrm{Ca}^{2+}$ regulates many physiological activities in the living cells, and plays a vital role in modulating intestinal absorption of glucose $[11,12]$. However, $\left[\mathrm{Ca}^{2+}\right]_{\text {cyt }}$ is finely controlled by calcium channels and transporters [13,14], which may finally regulate glucose absorption. Therefore, it is the major aim of this review to summarize the current knowledge about intestinal glucose absorption and the regulation by epithelial cation channels and transporters.

\section{Mechanisms of Glucose Absorption in the Intestine}

Complex carbohydrates reaching the small intestine must be hydrolyzed to monosaccharides such as glucose or galactose in order to be transported across the intestinal mucosa. The classical pathway of glucose absorption is across the intestinal brush-border membrane (BBM), which was predominantly mediated by SGLT1, a membrane protein that couples two molecules of $\mathrm{Na}^{+}$together with one molecule of glucose. The passive move out of the basolateral surface of enterocytes contains a facilitated-diffusion glucose transporter (GLUT2) which allows glucose to move from the IEC into the extracellular medium near the blood capillaries [15] (Figure 1). The absorption of glucose may be adjusted by other transporters, such as GLUT2 [16-18]. Translocation of GLUT2 from cytoplasmic vesicles into the apical membrane markedly increases the capacity of glucose uptake by the enterocyte [19-21]. Thus, any factor that influences the activities of SGLT1 and GLUT2 will also alter the absorption and metabolism of glucose.

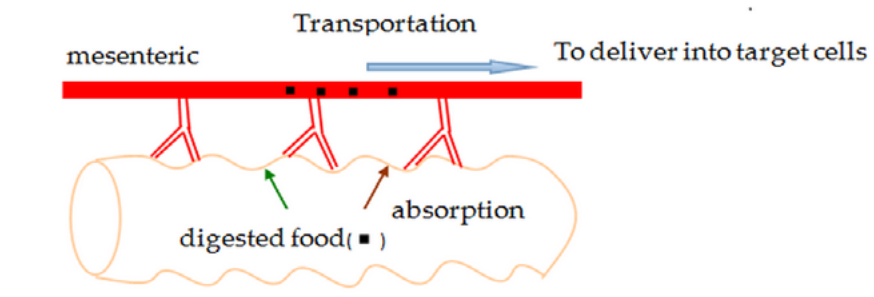

Small intestine(duodenum and Proximaljejunum)

Fig 1

Figure 1. Absorption of digested food (glucose) from the intestinal lumen into the blood, and transportation of the absorbed nutrients via mesenteric circulation to target cells. 


\section{Detection Methods of Glucose Absorption in Vitro}

At present, glucose absorption can be studied by two methods in vitro and in vivo. In vitro methods include tissue and cell experiments: (1) The Ussing chamber experiment uses intestinal tissues. Schultz and Zalusky were the first to use the short-circuit current to examine the electrical properties of rabbit ileum [22,23]. Specifically, they demonstrated via electrophysiological and radioisotopic experiments that the addition of glucose to the mucosal solutions resulted in a rapid increase in the transmural potential difference [24]. So this glucose-induced change in short-circuit currents was regarded as rates of glucose and $\mathrm{Na}^{+}$transports across the epithelium; (2) Then there is the application of the isotope tracer method in intestinal tissue and IEC. D- $(6-3 \mathrm{H})$ Glucose or ${ }^{14} \mathrm{C}$ glucose is used as the tracer to detect glucose absorption into intestinal tissue or IEC [25]; (3) To examine glucose absorption into a cell, glucose is absorbed into a cultural cell after glucose is added to the cell culture medium for a period of time, and the medium is then taken out for determining the concentrations of glucose by the hexokinase method or the glucose oxidizes/peroxides (GOD-POD) method [26].

\section{Regulation of Glucose Absorption by Potassium Channels}

\subsection{Potassium Channels in Small Intestinal Epithelial Cells}

The concentration of $\mathrm{K}^{+}$inside the cell is roughly 20 -fold larger than the outside. $\mathrm{K}^{+}$channels function to conduct potassium ions down their electrochemical gradient to maintain ion equilibrium, and provide electrochemical driving force to maintain cell function [27-29]. $\mathrm{K}^{+}$channels represent the largest and most heterogeneous family of ion channels and membrane proteins. They are widely expressed in both excitable and non-excitable cells [27,30,31]. In epithelial cells, $\mathrm{K}^{+}$channels are expressed in a polarized fashion and serve two principal functions for transepithelial transports: the generation of membrane potential and the recycling of $\mathrm{K}^{+}$[32]. As in duodenal epithelial cells, an intermediate-conductance $\mathrm{Ca}^{2+}$-activated $\mathrm{K}^{+}$channel $\left(\mathrm{IK}_{\mathrm{Ca}}\right)$ can provide a driving force for duodenal bicarbonate secretion [33]. On the intestinal mucosa surface, intermediate conductance $\mathrm{K}^{+}$ channels (KCNN4) can provide a driving force for $\mathrm{Cl}^{-}$secretion via both cystic fibrosis transmembrane conductance regulator(CFTR) and $\mathrm{Ca}^{2+}$-activated $\mathrm{Cl}^{-}$channels $(\mathrm{CaCC})$ that are mediated by cAMP and $\mathrm{Ca}^{2+}$ [34]. $\mathrm{K}^{+}$channels also regulate cell volume in isosmotic conditions in small intestinal epithelial cells [35]. Therefore, $\mathrm{K}^{+}$channels may be involved in various physiological processes of small intestinal epithelial cells. Especially, we deal with the regulatory mechanism of glucose absorption by $\mathrm{K}^{+}$channels.

\subsection{Regulatory Mechanisms of Glucose Absorption by Potassium Channels}

In the small intestine epithelial cells, $\mathrm{K}^{+}$channels provide the driving force required for $\mathrm{Na}^{+}$-dependent uptake of glucose into IEC. The glucose uptake is driven by the $\mathrm{Na}^{+}$transmembrane gradient and membrane potential (Em). Nevertheless, Em is primarily determined by plasmalemmal $\mathrm{K}^{+}$channels; the inhibition of $\mathrm{K}^{+}$channels (especially the voltage-gated potassium channels) in IEC would induce cell membrane depolarization and inhibit the nutrient absorption by reducing the driving force for $\mathrm{Na}^{+}$[36]. It was found that chromanol 293B, a selective blocker of KCNQ1 expressed in IEC, can enhance glucose tolerance and glucose-stimulated insulin secretion and plasma GLP-1 levels in cultured islets and intact animals [37]. Activation of ATP-sensitive $\mathrm{K}^{+}$channels (KATP) induces glucose-stimulated gastric inhibitory polypeptide release to finally affect glucose metabolism [38].

Hiroyuki Unoki identified KCNQ1 to be associated with susceptibility to type 2 diabetes [39,40]. $\mathrm{Kv} 1.3^{-/-}$mice gained significantly less weight than controls on a high-fat diet, but $\mathrm{Kv} 1.3^{+} /{ }^{+}$mice developed hyperglycemia [41]. There are different opinions as to how $\mathrm{K}^{+}$channels play a role in regulating blood glucose concentration. The blockade of $\mathrm{K}^{+}$channels in peripheral tissues is predominantly due to increasing peripheral insulin sensitivity, augmenting insulin release from pancreatic islets and increasing in basal metabolic rate [42-44]. However, some studies do not support a role for Kv1.3 channels in the regulation of glucose homeostasis or peripheral insulin sensitivity in 
mice or humans [45,46], but support their role in the regulation of obesity and diabetes by modulating electrophysiological characteristics of IEC.

The electrophysiological studies indicate that KCNE1-dependent $\mathrm{K}^{+}$movement from the cell to the lumen contributes to the maintenance of the electrical driving force for $\mathrm{Na}^{+}$-coupled transport in the proximal tubule [47]. However, $\mathrm{K}^{+}$channels that regulate glucose absorption in the small intestine have long been overlooked. The presented model of the absorption of glucose provides insight into how intestinal epithelial cells maintain intracellular ion homeostasis (Figure 2). The driving force for this transport protein is the $\mathrm{Na}^{+}$electrochemical gradient that is generated by the basolateral $\mathrm{Na}^{+} / \mathrm{K}^{+}$ATPase [48]. $\mathrm{Na}^{+} / \mathrm{K}^{+}$ATPase is an integral transmembrane protein in the basolateral membrane of mammalian IEC which extrudes three $\mathrm{Na}^{+}$and takes in two $\mathrm{K}^{+}$. This mechanism aids in maintaining the negative membrane potential of IEC to facilitate $\mathrm{Na}^{+}$entry across the luminal membrane, which drives the apical absorption of glucose in SGLT1 [49,50]. $\mathrm{K}^{+}$ electrochemical gradient also plays an important role in maintaining the activity of $\mathrm{Na}^{+} / \mathrm{K}^{+}$ATPase and membrane potential. Intracellular $\mathrm{K}^{+}$is recycled back across the basolateral membrane via $\mathrm{K}^{+}$ channels [51,52]. Karin Dedek demonstrated that KCNQ1 and KCNE3 are expressed in the basolateral localization of crypt cells of IEC and serve as a recycling pathway for $\mathrm{K}^{+}$to maintain basolateral $\mathrm{K}^{+}$ conductance [53]. McDaniel et al. demonstrated that Kv channel subunits (Kv1.1, Kv1.2, Kv1.3, Kv1.6, Kv7.1 and $\mathrm{K}_{\mathrm{Ca3} .1}$ ) are expressed in IEC. Inhibition of $\mathrm{Kv}$ channels by 4-AP or decrease of $\mathrm{K}^{+}$efflux by raising extracellular $\mathrm{K}^{+}$concentration induced membrane depolarization in IEC. Maintenance of membrane depolarization would reduce the transmembrane $\mathrm{Na}^{+}$driving force required for the $\mathrm{Na}^{+}$-dependent uptake of glucose [36]. Volker Vallon found that glucose-induced currents of small intestinal mucosa are reduced in KCNQ1 ${ }^{-/}$mice compared to wild-type mice [54], indicating an important role of KCNQ1 in regulating intestinal nutrient absorption. Basolateral $\mathrm{K}^{+}$channels and $\mathrm{Na}^{+} / \mathrm{K}^{+}$ATPase are found to hyperpolarize membrane potential, thereby increasing the driving force for other electrogenic transport systems and maintaining the homeostasis of ionic and nutrient substances [34,55-58]. However, specific types of $\mathrm{K}^{+}$channels that regulate glucose absorption and the underlying mechanisms still need further investigation.

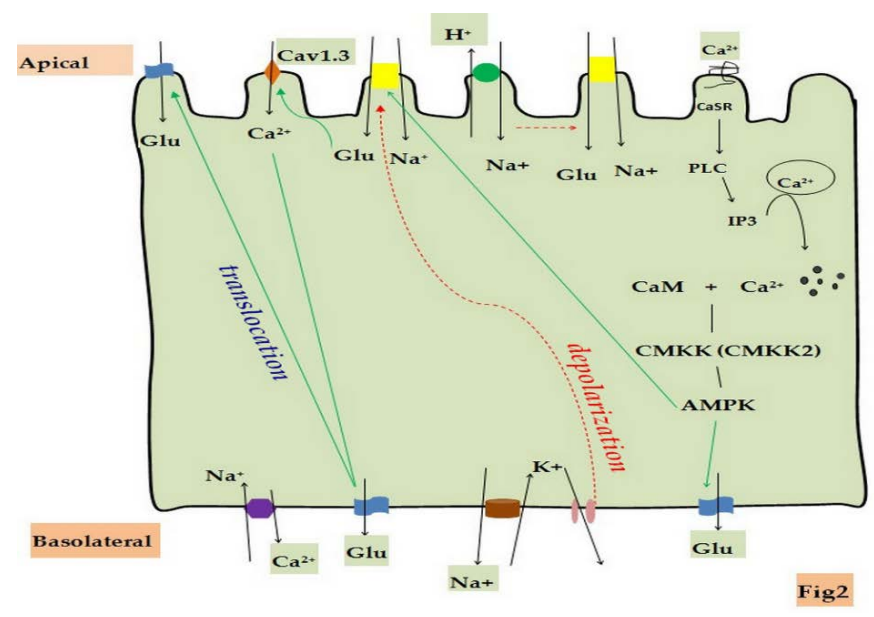

Figure 2. Schematic illustration of regulatory mechanisms of small intestinal glucose uptake by cation channels and transporters. Glucose absorption takes place in small intestinal villus cells by SGLT1, which is driven by active sodium extrusion via the basolateral $\mathrm{Na}^{+} / \mathrm{K}^{+}$ATPase. When basolateral $\mathrm{K}^{+}$ channels are closed to depolarize the membrane voltage, the electrogenic transportation of glucose is blocked. Intestinal glucose absorption is also up-regulated by $\mathrm{Ca}^{2+}$-dependent apical GLUT2 insertion. The $\left[\mathrm{Ca}^{2+}\right]_{\text {cyt }}$ is mainly excluded by NCX1 on the basolateral IEC. NHE3 suppresses SGLT1 and ultimately affects intestinal glucose absorption. Increased $\left[\mathrm{Ca}^{2+}\right]_{\text {cyt }}$ through CaSR is combined with CaM as a complex, which modulates AMPK and further activates SGLT1 or GLUT2 to adjust small intestinal glucose absorption. 


\section{Regulation of Glucose Absorption by Calcium Channels and Calcium-Sensing Receptors}

\subsection{Calcium Channels and Calcium-Sensing Receptors(CaSR) in Small Intestinal Epithelial Cells}

$\mathrm{Ca}^{2+}$ plays a critical role in most physiological activities of the body, including neurotransmitter release, muscle contraction, gene regulation, cell proliferation and apoptosis [59-61]. $\mathrm{Ca}^{2+}$ homeostasis of the body is mainly maintained by intestinal $\mathrm{Ca}^{2+}$ absorption and renal $\mathrm{Ca}^{2+}$ reabsorption. $\mathrm{Ca}^{2+}$ entry into brush border membranes (BBM) of enterocytes is mainly through epithelial $\mathrm{Ca}^{2+}$ channels: transient receptor potential vanilloid (such as TRPV5 and TRPV6) and voltage-operated channels L-type voltage-gated $\mathrm{Ca}^{2+}$ channels (such as $\mathrm{Ca}_{\mathrm{v}} 1.3$ ) [62-64]. In addition, $\mathrm{Ca}^{2+}$ influx is also controlled through the store-operated $\mathrm{Ca}^{2+}$ channel (SOC) [65]. These channels are expressed in the small intestinal epithelial cells and play important roles in intestinal absorption of calcium. Besides, the role of the CaSR is non-negligible in intestinal $\mathrm{Ca}^{2+}$ homeostasis [66]. The CaSR is a member of the G protein-coupled receptor (GPCR) C superfamily and is expressed in the entire digestive system [67].

\subsection{Regulatory Mechanisms of Glucose Absorption by Calcium Channels and CaSR}

It has been known that intestinal absorption of glucose is influenced by intracellular $\mathrm{Ca}^{2+}$ concentration; however, the underlying mechanisms are poorly understood for the $\mathrm{Ca}^{2+}$ regulation of glucose absorption. In the past study, Hyson and colleague observed that the kinetics of glucose uptake by SGLT1 were increased in the animals given two different types of calcium channel blockers, nisoldipine and verapamil [68]. Recently, a new model for $\mathrm{Ca}^{2+}$ regulation of intestinal glucose absorption has been proposed. When luminal glucose concentrations are low, intestinal glucose absorption is still mainly mediated by SGLT1 in IEC. However, when luminal glucose is higher than the ability of SGLT1 transport, the basal GLUT2 will be inserted at the apical cell membrane to participate in the absorption of glucose. These processes are regulated by $\left[\mathrm{Ca}^{2+}\right]_{\mathrm{cyt}}$, which also modulates GLUT2 expression in IEC [69,70]. Ca 1.3 has been found to play a role in the regulation of $\mathrm{Ca}^{2+}$ absorption through glucose stimulation [71]. Studies have pointed out that the translocation of GLUT2 from the intracellular pool is triggered by the SGLT1-dependent activation of protein Kinase C and MAP-Kinase pathways, which are associated with $\left[\mathrm{Ca}^{2+}\right]_{\mathrm{cyt}}[72]$. Morgan et al. also demonstrated that intestinal $\mathrm{Ca}^{2+}$ absorption via Cav1.3 does indeed play an important role in the regulation of intestinal glucose absorption by controlling apical GLUT2 insertion [73]. Subsequently, Morgan et al. found that depolarization of the apical membrane by glucose absorption through SGLT1 actives the influx of luminal $\mathrm{Ca}^{2+}$ via $\mathrm{Ca}_{\mathrm{v}} 1.3$ [74]. An increase in $\left[\mathrm{Ca}^{2+}\right]_{c y t}$ activates the calmodulin-dependent myosin light chain kinase (MLCK), further activating myosin II in the terminal web by phosphorylation of the regulatory light chain (RLC20) at Ser19. These biological processes lead to cytoskeletal rearrangement and eventually result in the translocation of GLUT2 to apical cell membranes [14,75].

The CaSR plays an important role in the regulation of $\left[\mathrm{Ca}^{2+}\right]_{\mathrm{cyt}}$. Activation of the CaSR on apical or basolateral membranes results in a rise in $\left[\mathrm{Ca}^{2+}\right]_{\mathrm{cyt}}$, which is mediated by the generation of inositol 1,4,5-trisphosphate $\mathrm{IP}_{3}$ via phospholipase $\mathrm{C}$ (PLC) and then the release of $\mathrm{Ca}^{2+}$ from a thapsigargin-sensitive pool [76,77]. Intracellular $\mathrm{Ca}^{2+}$ binds with $\mathrm{CaM}$ as a compound, activating a plethora of enzymes, including calcium/calmodulin-dependent protein kinase 2 (CaMKK2) [78]. David Carling and colleagues have demonstrated that pharmacological inhibition of CaMKK or downregulation of CaMKK $\beta$ using RNA interference almost completely suppresses AMPK activation [79], a key sensor of energy status within the cell that has been demonstrated to play roles in the regulation of cellular glucose uptake. Currently, regulation of glucose uptake by AMPK is controversial. Some scholars support that AMPK enhances cellular glucose uptake through the increased translocation of GLUT2 to the brush border membrane(BBM) [80,81], whereas other scholars hold that AMPK increases cellular glucose uptake via raising the expression of SGLT1 in cell membranes [82]. 


\section{Regulation of Glucose Absorption by Transporters}

\subsection{Transporters in Small Intestinal Epithelial Cells}

Several transporters play vital roles in maintaining the electrophysiological characteristics of small intestinal epithelial cells. $\mathrm{Na}^{+} / \mathrm{Ca}^{2+}$ exchangers (NCX) and sodium hydrogen exchangers (NHE) are found to express in the small intestinal epithelium [83]. NHE is a major non-nutritive $\mathrm{Na}^{+}$absorptive pathway of the intestine. Nine members of the NHE family were cloned. NHE plays a key role in regulating the intracellular $\mathrm{pH}$ and cell volume and the referring event during such processes including cell proliferation, differentiation, apoptosis and so on [84-86]. Plasma membrane NHE characterized to date in animal cells utilizes the inward $\mathrm{Na}^{+}$gradient created by the activity of $\mathrm{Na}^{+} / \mathrm{K}^{+}$-ATPase to extrude $\mathrm{H}^{+}$against its electrochemical gradient in an electroneutral fashion. It is therefore not surprising that NHE3 can regulate the activity of SGLT1 and then intestinal glucose absorption [50]. On the other hand, the NCX family exists in three subtypes (NCX1-3) with different tissue distributions, which plays a role in the regulation of duodenal mucosal ion transport and $\mathrm{HCO}_{3}{ }^{-}$ secretion by controlling $\mathrm{Ca}^{2+}$ homeostasis [87]. The role of $\mathrm{Na}^{+} / \mathrm{Ca}^{2+}$ exchangers in the intestinal tract remains unclear.

\subsection{Regulatory Mechanisms of Glucose Absorption by Transporters}

It is well known that $\mathrm{Na}^{+}$enters IEC via two primary pathways: SGLT1 and NHE3, which are expressed on the apical side of the small intestinal epithelium [88]. Using small interfering RNA to silence NHE3 significantly increases the SGLT1 activity of the brush border membrane in rat small intestinal cell (IEC-18) monolayers due to an increase in the number of SGLT1 [89], indicating NHE3 can regulate glucose absorption by modulating the expression of SGLT1. The regulatory mechanism of glucose absorption by NHE3 may be associated with the MAPKe-activated protein kinase 2 (MAPKAPK-2), which is activated by p38 mitogen-activated protein kinase (p38 MAPK) and finally directly phosphorylates Akt2 as well as NHE3 translocation to mediate $\mathrm{Na}^{+}$absorption and $\mathrm{Na}^{+}$-glucose cotransport [90]. In another way, it was also found that elevated $\left[\mathrm{Ca}^{2+}\right]_{\mathrm{cyt}}$ can inhibit NHE3 activity to regulate $\mathrm{Na}^{+}$absorption in small intestinal brush border [91]. Therefore, NHE3 regulation of intestinal glucose absorption could be carried out by different mechanisms.

NCX1 is mainly responsible for the cellular balance of $\mathrm{Ca}^{2+}$ and $\mathrm{Na}^{+}$. NCX1 can operate in either a forward mode $\left(\mathrm{Ca}^{2+}\right.$ exit) or in a reversed mode $\left(\mathrm{Ca}^{2+}\right.$ entry), depending on the $\mathrm{Na}^{+}$and $\mathrm{Ca}^{2+}$ gradients and the potential across the plasma membrane [92]. The $\left[\mathrm{Ca}^{2+}\right]_{\mathrm{cyt}}$ and $\left[\mathrm{Na}^{+}\right]_{\mathrm{cyt}}$ in IEC is regulated by NCX1 expressed on both apical and basolateral sides $[64,83,93]$. Since $\left[\mathrm{Ca}^{2+}\right]_{\mathrm{cyt}}$ and $\left[\mathrm{Na}^{+}\right]_{\text {cyt }}$ play important roles in the regulation of intestinal glucose absorption, NCX1 may be also involved in this regulatory mechanism. Unfortunately, there is no information on NCX1 regulation of intestinal glucose absorption, which might be a new direction for future research.

\section{Conclusions}

Small intestine absorption of excess glucose is associated with obesity and diabetes. However, at present, studies on the regulatory mechanisms of intestinal glucose absorption are very limited and mainly concentrate on SGLT1 [94]. Recent growing evidence suggests the involvement of cation channels, transporters and CaSR in the regulation of intestinal glucose absorption. However, further studies are needed to confirm their contributions to the regulation of glucose uptake and to elucidate the underlying mechanisms. If cation channels and transporters in IEC are confirmed to truly play important roles in modulating intestinal glucose absorption, they may become novel targets for drug discovery to treat obesity and diabetes, which are common and serious human diseases.

Acknowledgments: The work was supported by the National Natural Science Foundation of China (No. 31371167 and No. 81570477) to Hui Dong, and the National Natural Science Foundation of China (NO. 81160054) to Biguang Tuo. 
Author Contributions: H.D. and L.H.C. conceived and designed the review. L.H.C. wrote the review. H.D. and B.G.T. revised the review. All authors discussed and approved the final version.

Conflicts of Interest: The authors declare no conflict of interest.

\section{References}

1. An, R. Prevalence and trends of adult obesity in the US, 1999-2012. ISRN Obes. 2014, 2014, 185132. [CrossRef] [PubMed]

2. Kim, S.E.; Ahn, H.S.; Choi, B.H.; Jang, H.J.; Kim, M.J.; Rhie, D.J.; Yoon, S.H.; Jo, Y.H.; Kim, M.S.; Sung, K.W.; et al. Open channel block of a-type, Kv4.3, and delayed rectifier $\mathrm{k}^{+}$channels, Kv1.3 and Kv3.1, by sibutramine. J. Pharmacol. Exp. Ther. 2007, 321, 753-762. [CrossRef] [PubMed]

3. Crane, R.K. Na ${ }^{+}$-dependent transport in the intestine and other animal tissues. Fed. Proc. 1965, 24, $1000-1006$. [PubMed]

4. Gorboulev, V.; Schürmann, A.; Vallon, V.; Kipp, H.; Jaschke, A.; Klessen, D.; Friedrich, A.; Scherneck, S.; Rieg, T.; Cunard, R. Na ${ }^{+}$-D-glucose cotransporter SGLT11 is pivotal for intestinal glucose absorption and glucose dependent incretin secretion. Diabetes 2011, 61, 187-196. [CrossRef] [PubMed]

5. Hirsch, J.R.; Loo, D.D.; Wright, E.M. Regulation of $\mathrm{Na}^{+}$/glucose cotransporter expression by protein kinases in xenopus laevis oocytes. J. Biol. Chem. 1996, 271, 14740-14746. [PubMed]

6. Alexander, A.N.; Carey, H.V. Involvement of PI 3-kinase in IGF-I stimulation of jejunal na ${ }^{+}-\mathrm{k}^{+}$-atpase activity and nutrient absorption. Am. J. Physiol. Gastrointest. L. 2001, 280, G222-G228.

7. Casselbrant, A.; Malinauskas, M.; Marschall, H.U.; Wallenius, V.; Fändriks, L. Angiotensin II exerts dual actions on sodium-glucose transporter 1-mediated transport in the human jejunal mucosa. Scand. J. Gastroentero. 2015, 50, 1068-1075. [CrossRef] [PubMed]

8. Umbach, J.A.; Coady, M.J.; Wright, E.M. Intestinal Na ${ }^{+}$-glucose cotransporter expressed in xenopus oocytes is electrogenic. Biophys. J. 1990, 57, 1217-1224. [CrossRef]

9. Wang, J.Y.; Wang, J.; Golovina, V.A.; Li, L.; Platoshyn, O.; Yuan, J.X. Role of $\mathrm{K}^{+}$channel expression in polyamine-dependent intestinal epithelial cell migration. Am. J. Physiol. Cell Physiol. 2000, 278, C303-C314. [PubMed]

10. Silver, K.; Littlejohn, A.; Thomas, L.; Marsh, E.; Lillich, J.D. Inhibition of Kv channel expression by nsaids depolarizes membrane potential and inhibits cell migration by disrupting calpain signaling. Biochem. Pharmacol. 2015, 98, 614-628. [CrossRef] [PubMed]

11. Sheptitski $\breve{i}$, V.A.; Guska, N.I. $\mathrm{Ca}^{2+}$-dependent glucose absorption in the small intestine of rats under head-down tilt stress. Fiziologicheskĭ Zhurnal Imeni I.M. Sechenova 1996, 82, 125-130. [PubMed]

12. Gurman, E.G. The characteristics of the action of calcium antagonists on glucose transport in the rat small intestine. Fiziologicheskii Zhurnal Imeni I.M. Sechenova 1990, 76, 509-514.

13. Christakos, S.; Dhawan, P.; Ajibade, D.; Benn, B.S.; Feng, J.; Joshi, S.S. Mechanisms involved in vitamin D mediated intestinal calcium absorption and in non-classical actions of vitamin D. J. Steroid. Biochem. Mol. Biol. 2010, 121, 183-187. [CrossRef] [PubMed]

14. Mace, O.J.; Morgan, E.L.; Affleck, J.A.; Lister, N.; Kellett, G.L. Calcium absorption by Cav1.3 induces terminal web myosin II phosphorylation and apical GLUT2 insertion in rat intestine. J. Physiol. 2007, 580, 605-616. [CrossRef] [PubMed]

15. Röder, P.V.; Geillinger, K.E.; Zietek, T.S.; Thorens, B.; Koepsell, H.; Daniel, H. The role of SGLT1 and GLUT2 in intes tinal glucose transportand sensing. PLoS ONE 2014, 26, e89977. [CrossRef] [PubMed]

16. Boudry, G.; Cheeseman, C.I.; Perdue, M.H. Psychological stress impairs $\mathrm{Na}^{+}$-dependent glucose absorption and increases GLUT2 expression in the rat jejunal brush-border membrane. Am. J. Physiol. Regul. 2007, 292, R862-R867. [CrossRef] [PubMed]

17. Ait-Omar, A.; Monteiro-Sepulveda, M.; Poitou, C.; le Gall, M.; Cotillard, A.; Gilet, J.; Garbin, K.; Houllier, A.; Château, D.; Lacombe, A. GLUT2 accumulation in enterocyte apical and intracellular membranes. Diabetes 2011, 60, 2598-2607. [CrossRef] [PubMed]

18. Chaudhry, R.M.; Scow, J.S.; Madhavan, S.; Duenes, J.A.; Sarr, M.G. Acute enterocyte adaptation to luminal glucose: A posttranslational mechanism for rapid apical recruitment of the transporter glut2. J. Gastrointest. Surg. 2012, 16, 312-319. [CrossRef] [PubMed] 
19. Affleck, J.A.; Helliwell, P.A.; Kellett, G.L. Immunocytochemical detection of GLUT2 at the rat intestinal brush-border membrane. J. Histochem. Cytochem. 2003, 51, 1567-1574. [CrossRef] [PubMed]

20. Zheng, Y.; Scow, J.S.; Duenes, J.A.; Sarr, M.G. Mechanisms of glucose uptake in intestinal cell lines: Role of GLUT2. Surgery 2012, 151, 13-25. [CrossRef] [PubMed]

21. Grefner, N.M.; Gromova, L.V.; Gruzdkov, A.A.; Komissarchik, I. Interaction of glucose transporters SGLT1 and GLUT2 with cytoskeleton in enterocytes and caco2 cells during hexose absorption. Cell Tissue Biol. 2015, 9, 45-52. [CrossRef]

22. Schultz, S.G.; Zalusky, R. Ion transport in isolated rabbit ileum I. Short-circuit current and na fluxes. J. Gen. Physiol. 1964, 47, 567-584. [CrossRef] [PubMed]

23. Schultz, S.G.; Zalusky, R. Ion transport in isolated rabbit II. The interaction between active active sugar transport. J. Gen. Physiol. 1964, 47, 1043-1059. [CrossRef] [PubMed]

24. Hamilton, K.L.; Butt, A.G. Glucose transport into everted sacs of the small intestine of mice. Adv. Physiol. Educ. 2013, 37, 415-426. [CrossRef] [PubMed]

25. Johnston, K.; Sharp, P.; Clifford, M.; Morgan, L. Dietary polyphenols decrease glucose uptake by human intestinal caco-2 cells. FEBS Lett. 2005, 579, 1653-1657. [CrossRef] [PubMed]

26. Liu, M.Y.; Wang, W.F.; Yu, Y.X.; Hou, Y.T.; Ren, G.P.; Li, D.S. FGF-21 improves glucose uptake and glycogen synthesis of insulin-resistant liver cells. Prog. Biochem. Biophys. 2009, 36, 1327-1333. [CrossRef]

27. Carrisoza-Gaytán, R.; Salvador, C.; Diaz-Bello, B.; Escobar, L. Differential expression of the Kv1 voltage-gated potassium channel family in the rat nephron. J. Mol. Histol. 2014, 45, 583-597. [CrossRef] [PubMed]

28. Kirchheim, F.; Tinnes, S.; Haas, C.A.; Stegen, M.; Wolfart, J. Regulation of action potential delays via voltage-gated potassium Kv1.1 channels in dentate granule cells during hippocampal epilepsy. Front. Cell. Neurosci. 2013, 7, 248. [CrossRef] [PubMed]

29. Pan, Q.; Ma, J.; Zhou, Q.; Li, J.; Tang, Y.; Liu, Y.; Yang, Y.; Xiao, J.; Peng, L. KCNQ1 loss-of-function mutation impairs gastric acid secretion in mice. Mol. Biol. Rep. 2010, 37, 1329-1333. [CrossRef] [PubMed]

30. Yang, J.E.; Song, M.S.; Ryu, P.D.; Lee, S.Y. The role of voltage-gated potassium channels in osteogenic differentiation. FASEB J. 2015, 29, 1.

31. Hristov, K.L.; Chen, M.; Soder, R.P.; Parajuli, S.P.; Cheng, Q.; Kellett, W.F.; Petkov, G.V. Kv2.1 and electrically silent $\mathrm{Kv}$ channel subunits control excitability and contractility of guinea pig detrusor smooth muscle. Am. J. Physiol. Cell. Physiol. 2011, 302, C360-C372. [CrossRef] [PubMed]

32. Li, Y.F.; Zhuo, Y.H.; Bi, W.N.; Bai, Y.J.; Li, Y.N.; Wang, Z.J. Voltage-gated potassium channel Kv1.3 in rabbit ciliary epithelium regulates the membrane potential via coupling intracellular calcium. Chin. Med. J. 2008, 121, 2272-2277. [PubMed]

33. Xie, R.; Dong, X.; Wong, C.; Vallon, V.; Tang, B.; Sun, J.; Yang, S.; Dong, H. Molecular mechanisms of calcium-sensing receptor-mediated calcium signaling in the modulation of epithelial ion transport and bicarbonate secretion. J. Biol. Chem. 2014, 289, 34642-34653. [CrossRef] [PubMed]

34. Nanda Kumar, N.S.; Singh, S.K.; Rajendran, V.M. Mucosal potassium efflux mediated via Kcnn4 channels provides the driving force for electrogenic anion secretion in colon. Am. J. Physiol. Gastrointest. 2010, 299, G707-G714. [CrossRef] [PubMed]

35. Lionetto, M.G.; Giordano, M.E.; de Nuccio, F.; Nicolardi, G.; Hoffmann, E.K.; Schettino, T. Hypotonicity induced $\mathrm{K}^{+}$and anion conductive pathways activation in eel intestinal epithelium. J. Exp. Biol. 2005, 208, 749-760. [CrossRef] [PubMed]

36. McDaniel, S.S.; Platoshyn, O.; Yu, Y.; Sweeney, M.; Miriel, V.A.; Golovina, V.A.; Krick, S.; Lapp, B.R.; Wang, J.Y.; Yuan, J.X. Anorexic effect of $\mathrm{k}^{+}$channel blockade in mesenteric arterial smooth muscle and intestinal epithelial cells. J. Appl. Physiol. 2001, 91, 2322-2333. [PubMed]

37. Liu, L.; Wang, F.; Lu, H.; Ren, X.; Zou, J. Chromanol 293b, an inhibitor of kcnq1 channels, enhances glucose-stimulated insulin secretion and increases glucagon-like peptide-1 level in mice. Islets 2014, 6, e962386. [CrossRef] [PubMed]

38. Parker, H.E.; Habib, A.M.; Rogers, G.J.; Gribble, F.M.; Reimann, F. Nutrient-dependent secretion of glucose-dependent insulinotropic polypeptide from primary murine k cells. Diabetologia 2009, 52, 289-298. [CrossRef] [PubMed]

39. Unoki, H.; Takahashi, A.; Kawaguchi, T.; Hara, K.; Horikoshi, M.; Andersen, G.; Ng, D.P.; Holmkvist, J.; Borch-Johnsen, K. SNPs in KCNQ1 are associated with susceptibility to type 2 diabetes in east asian and european populations. Nat. Genet. 2008, 40, 1098-1102. [CrossRef] [PubMed] 
40. Saif-Ali, R.; Ismail, I.S.; Al-Hamodi, Z.; Al-Mekhlafi, H.M.; Siang, L.C.; Alabsi, A.M.; Muniandy, S. KCNQ1 haplotypes associate with type 2 diabetes in malaysian chinese subjects. Int. J. Mol. Sci. 2011, 12, 5705-5718. [CrossRef] [PubMed]

41. Xu, J.; Koni, P.A.; Wang, P.; Li, G.; Kaczmarek, L.; Wu, Y.; Li, Y.; Flavell, R.A.; Desir, G.V. The voltage-gated potassium channel Kv1.3 regulates energy homeostasis and body weight. Hum. Mol. Genet. 2003, 12, 551-559. [CrossRef] [PubMed]

42. Upadhyay, S.K.; Eckel-Mahan, K.L.; Mirbolooki, M.R.; Tjong, I.; Griffey, S.M.; Schmunk, G.; Koehne, A.; Halbout, B.; Iadonato, S. Selective Kv1.3 channel blocker as therapeutic for obesity and insulin resistance. Proc. Natl. Acad. Sci. USA 2013, 110, E2239-E2248. [CrossRef] [PubMed]

43. Tucker, K.; Overton, J.M.; Fadool, D.A. Diet-induced obesity resistance of Kv1.3-/- mice is olfactory bulb dependent. J. Neuroendocrinol. 2012, 24, 1087-1095. [CrossRef] [PubMed]

44. Müssig, K.; Staiger, H.; Machicao, F.; Kirchhoff, K.; Guthoff, M.; Schäfer, S.A.; Kantartzis, K.; Silbernagel, G.; Stefan, N. Association of type 2 diabetes candidate polymorphisms in kcnq1 with incretin and insulin secretion. Diabetes 2009, 58, 1715-1720. [CrossRef] [PubMed]

45. Straub, S.V.; Perez, S.M.; Tan, B.; Coughlan, K.A.; Trebino, C.E.; Cosgrove, P.; Buxton, J.M.; Kreeger, J.M.; Jackson, V.M. Pharmacological inhibition of Kv1.3 fails to modulate insulin sensitivity in diabetic mice or human insulin-sensitive tissues. Am. J. Physiol. Endocrinol. Metab. 2011, 301, E380-E390. [CrossRef] [PubMed]

46. Ngala, R.A.; Zaibi, M.S.; Langlands, K.; Stocker, C.J.; Arch, J.R.; Cawthorne, M.A. Stimulation of glucose uptake in murine soleus muscle and adipocytes by 5-(4-phenoxybutoxy)psoralen (PAP-1) may be mediated by Kv1.5 rather than Kv1.3. Peer J. 2014, 2, e614. [CrossRef] [PubMed]

47. Vallon, V.; Grahammer, F.; Richter, K.; Bleich, M.; Lang, F.; Barhanin, J.; Völkl, H.; Warth, R. Role of KCNE1-dependent $\mathrm{K}^{+}$fluxes in mouse proximal tubule. J. Am. Soc. Nephrol. 2001, 12, 2003-2011. [PubMed]

48. Gal-Garber, O.; Mabjeesh, S.J.; Sklan, D.; Uni, Z. Nutrient transport in the small intestine:Na+, $\mathrm{K}^{+}$-ATPase expression and activity in the small intestine of the chicken as influenced by dietary sodium. Poult. Sci. 2003, 82, 1127-1133. [CrossRef] [PubMed]

49. Thorsen, K.; Drengstig, T.; Ruoff, P. Transepithelial glucose transport and $\mathrm{Na}^{+} / \mathrm{K}^{+}$homeostasis in enterocytes: An integrative model. Am. J. Physiol. Cell Physiol. 2014, 307, C320-C337. [CrossRef] [PubMed]

50. Palanikumar, M.; Swapna, G.; Subha, A.; Balasubramanian, P.; Soudamani, S.; Gregory, M.D.; Uma, S. Chronic and selective inhibition of basolateral membrane Na-K-ATPase uniquely regulates brush border membrane na absorption in intestinal epithelial cells. Am. J. Physiol. Cell Phys. 2015, 308, C650-C656.

51. Chiba, T.; Marcus, D.C. Basolateral $\mathrm{K}^{+}$conductance establishes driving force for cation absorption by outer sulcus epithelial cells. J. Membr. Biol. 2001, 184, 101-112. [CrossRef] [PubMed]

52. Bajwa, P.J.; Alioua, A.; Lee, J.W.; Straus, D.S.; Toro, L.; Lytle, C. Fenofibrate inhibits intestinal $\mathrm{Cl}^{-}$secretion by blocking basolateral KCNQ1 K+ channels. Am. J. Physiol. Gastrl. 2007, 293, G1288-G1299. [CrossRef] [PubMed]

53. Dedek, K.; Waldegger, S. Colocalization of KCNQ1/KCNE channel subunits in the mouse gastrointestinal tract. Pflugers. Arch. 2001, 442, 896-902. [CrossRef] [PubMed]

54. Vallon, V.; Grahammer, F.; Volkl, H.; Sandu, C.D.; Richter, K.; Rexhepaj, R.; Gerlach, U.; Rong, Q.; Pfeifer, K.; Lang, F. KCNQ1-dependent transport in renal and gastrointestinal epithelia. Proc. Natl. Acad. Sci. USA 2005, 102, 17864-17869. [CrossRef] [PubMed]

55. Pouokam, E.; Bader, S.; Brück, B.; Schmidt, B.; Diener, M. ATP-sensitive $\mathrm{K}^{+}$channels in rat colonic epithelium. Pflug. Arch. Eur. J. Phys. 2013, 465, 865-877. [CrossRef] [PubMed]

56. Hamilton, K.L.; Devor, D.C. Basolateral membrane $\mathrm{K}^{+}$channels in renal epithelial cells. Am. J. Physiol. Renal 2012, 302, F1069-F1078. [CrossRef] [PubMed]

57. Preston, P.; Wartosch, L.; Günzel, D.; Fromm, M.; Kongsuphol, P.; Ousingsawat, J.; Kunzelmann, K.; Barhanin, J.; Warth, R.; Jentsch, T. Disruption of the $\mathrm{K}^{+}$channel $\beta$-subunit KCNE3 reveals an important role in intestinal and tracheal $\mathrm{Cl}^{-}$transport. J. Biol. Chem. 2010, 285, 7165-7175. [CrossRef] [PubMed]

58. Turnheim, K.; Plass, H.; Wyskovsky, W. Basolateral potassium channels of rabbit colon epithelium: Role in sodium absorption and chloride secretion. Biochim. Biophys. Acta 2002, 1560, 51-66. [CrossRef]

59. Khuzakhmetova, V.F.; Samigullin, D.V.; Bukharaeva, E.A. The role of presynaptic ryanodine receptors in regulation of the kinetics of the acetylcholine quantal release in the mouse neuromuscular junction. Biol. Membr. 2014, 30, 499-508. [CrossRef] 
60. Huang, W.; Lu, C.; Wu, Y.; Ouyang, S.; Chen, Y. T-type calcium channel antagonists, mibefradil and NNC-55-0396 inhibit cell proliferation and induce cell apoptosis in leukemia cell lines. J. Exp. Clin. Cancer. Res. 2015, 34. [CrossRef] [PubMed]

61. Liu, X.R.; Zhang, M.F.; Yang, N.; Liu, Q.; Wang, R.X.; Cao, Y.N.; Yang, X.R.; Sham, J.S.; Lin, M.J. Enhanced store-operated $\mathrm{Ca}^{2+}$ entry and TRPC channel expression in pulmonary arteries of monocrotaline-induced pulmonary hypertensive rats. Am. J. Physiol. Cell Physiol. 2012, 302, C77-C87. [CrossRef] [PubMed]

62. Woudenberg-Vrenken, T.E.; Lameris, A.L.; Weißgerber, P.; Olausson, J.; Flockerzi, V.; Bindels, R.J.; Freichel, M.; Hoenderop, J.G. Functional TRPV6 channels are crucial for transepithelial $\mathrm{Ca}^{2+}$ absorption. Am. J. Physiol. Gastrointest. 2012, 303, G879-G885. [CrossRef] [PubMed]

63. Benn, B.S.; Ajibade, D.; Porta, A.; Dhawan, P.; Hediger, M.; Peng, J.B.; Jiang, Y.; Oh, G.T.; Jeung, E.B.; Lieben, L. Active intestinal calcium transport in the absence of transient receptor potential vanilloid Type 6 and calbindin-D(9k). Endocrinology 2008, 149, 3196-3205. [CrossRef] [PubMed]

64. Hwang, I.; Jung, E.M.; Yang, H.; Choi, K.C.; Jeung, E.B. Tissue-specific expression of the calcium transporter genes TRPV5, TRPV6, NCX1, and PMCA1b in the duodenum, kidney and heart of equus caballus. J. Vet. Med. Sci. 2011, 73, 1437-1444. [CrossRef] [PubMed]

65. Chung, H.K.; Rathor, N.; Wang, S.R.; Wang, J.Y.; Rao, J.N. Rhoa enhances store-operated Ca ${ }^{2+}$ entry and intestinal epithelial restitution by interacting with trpc1 after wounding. Am. J. Physiol. Gastrointest. 2015, 309, G759-G767. [CrossRef] [PubMed]

66. Brown, E.M. Role of the calcium-sensing receptor in extracellular calcium homeostasis. Best. Pract. Res. Clin. Endocrinol. Metab. 2013, 27, 333-343. [CrossRef] [PubMed]

67. Diaz, R.; Hurwitz, S.; Chattopadhyay, N.; Pines, M.; Yang, Y.; Kifor, O.; Einat, M.S.; Butters, R.; Hebert, S.C.; Brown, E.M. Cloning, expression, and tissue localization of the calcium-sensing receptor in chicken (gallus domesticus). Am. J. Physiol. 1997, 273, R1008-R1016. [PubMed]

68. Hyson, D.A.; Thomson, A.B.; Kappagoda, C.T. Calcium channel blockers modify jejunal uptake of D-galactose in rabbits. Dig. Dis. Sci. 1996, 41, 1871-1875. [CrossRef] [PubMed]

69. Tharabenjasin, P.; Douard, V.; Patel, C.; Krishnamra, N.; Johnson, R.J.; Zuo, J.; Ferraris, R.P. Acute interactions between intestinal sugar and calcium transport in vitro. Am. J. Physiol. Gastrointest. 2013, 306, G1-G12. [CrossRef] [PubMed]

70. Kuhre, R.E.; Bechmann, L.E.; Albrechtsen, N.J.W.; Hartmann, B.; Holst, J.J. Glucose stimulates neurotensin secretion from the rat small intestine by mechanisms involving sglt1 and glut2 leading to cell depolarization and calcium influx. Am. J. Physiol. Endoc. Metab. 2015, 308, E1123-E1130. [CrossRef] [PubMed]

71. Nakkrasae, L.I.; Thongon, N.; Thongbunchoo, J.; Krishnamra, N.; Charoenphandhu, N. Transepithelial calcium transport in prolactin-exposed intestine-like caco-2 monolayer after combinatorial knockdown of TRPV5, TRPV6 and Cav1.3. J. Physiol. Sci. 2010, 60, 9-17. [CrossRef] [PubMed]

72. Helliwell, P.A.; Rumsby, M.G.; Kellett, G.L. Intestinal sugar absorption is regulated by phosphorylation and turnover of protein kinase C $\beta$ II mediated by phosphatidylinositol 3-kinase- and mammalian target of rapamycin-dependent pathways. J. Biol. Chem. 2003, 278, 28644-28650. [CrossRef] [PubMed]

73. Morgan, E.L.; Mace, O.J.; Affleck, J.; Kellett, G.L. Apical GLUT2 and Cav1.3: Regulation of rat intestinal glucose and calcium absorption. J. Physiol. 2007, 580, 593-604. [CrossRef] [PubMed]

74. Morgan, E.L.; Mace, O.J.; Helliwell, P.A.; Affleck, J.; Kellett, G.L. A role for Cav1.3 in rat intestinal calcium absorption. Biochem. Biophys. Res. Commun. 2003, 312, 487-493. [CrossRef] [PubMed]

75. Bourzac, J.F.; L’Ériger, K.; Larrivée, J.F.; Arguin, G.; Bilodeau, M.S.; Stankova, J.; Gendron, F.P. Glucose transporter 2 expression is down regulated following P2X7 activation in enterocytes. J. Cell. Physiol. 2013, 228, 120-129. [CrossRef] [PubMed]

76. Cheng, S.X.; Okuda, M.; Hall, A.E.; Geibel, J.P.; Hebert, S.C. Expression of calcium-sensing receptor in rat colonic epithelium: Evidence for modulation of fluid secretion. Am. J. Physiol. Gastrointest. 2002, 283, G240-G250. [CrossRef] [PubMed]

77. Geibel, J.P.; Hebert, S.C. The functions and roles of the extracellular $\mathrm{Ca}^{2+}$-sensing receptor along the gastrointestinal tract. Annu. Rev. Physiol. 2009, 71, 205-217. [CrossRef] [PubMed]

78. Stahmann, N.; Woods, A.; Carling, D.; Heller, R. Thrombin activates AMP-activated protein kinase in endothelial cells via a pathway involving $\mathrm{Ca}^{2+} /$ calmodulin-dependent protein kinase kinase $\beta$. Mol. Cell. Biol. 2006, 26, 5933-5945. [CrossRef] [PubMed] 
79. Woods, A.; Dickerson, K.; Heath, R.; Hong, S.P.; Momcilovic, M.; Johnstone, S.R.; Carlson, M.; Carling, D. $\mathrm{Ca}^{2+} /$ calmodulin-dependent protein kinase kinase- $\beta$ acts upstream of AMP-activated protein kinase in mammalian cells. Cell Metab. 2005, 2, 21-33. [CrossRef] [PubMed]

80. Gabler, N.K.; Radcliffe, J.S.; Spencer, J.D.; Webel, D.M.; Spurlock, M.E. Feeding long-chain n-3 polyunsaturated fatty acids during gestation increases intestinal glucose absorption potentially via the acute activation of ampk. J. Nutr. Biochem. 2009, 20, 17-25. [CrossRef] [PubMed]

81. Walker, J.; Jijon, H.B.; Diaz, H.; Salehi, P.; Churchill, T.; Madsen, K.L. 5-aminoimidazole-4-carboxamide riboside (AICAR) enhances GLUT2-dependent jejunal glucose transport: A possible role for ampk. Biochem. J. 2005, 385, 485-491. [CrossRef] [PubMed]

82. Sopjani, M.; Bhavsar, S.K.; Fraser, S.; Kemp, B.E.; Foller, M.; Lang, F. Regulation of $\mathrm{Na}^{+}$-coupled glucose carrier SGLT1 by AMP-activated protein kinase. Mol. Membr. Biol. 2010, 27, 137-144. [CrossRef] [PubMed]

83. Wu, P.; Xie, F.; Xue, M.; Xu, X.; He, S.; Lin, M.; Bai, L. Advanced oxidation protein products decrease the expression of calcium transport channels in small intestinal epithelium via the p44/42 mapk signaling pathway. Eur. J. Cell. Biol. 2015, 94, 190-203. [CrossRef] [PubMed]

84. Lu, Z.; Yao, L.; Jiang, Z.; Aschenbach, J.R.; Martens, H.; Shen, Z. Acidic PH and short-chain fatty acids activate $\mathrm{Na}$ transport but differentially modulate expression of $\mathrm{Na} / \mathrm{H}$ exchanger isoforms 1,2 , and 3 in omasal epithelium. J. Dairy Sci. 2016, 99, 733-745. [CrossRef] [PubMed]

85. Jacob, P.; Rossmann, H.; Lamprecht, G.; Kretz, A.; Neff, C.; Lin-Wu, E.; Gregor, M.; Groneberg, D.A. Down-regulated in adenoma mediates apical $\mathrm{Cl}^{-} / \mathrm{HCO}_{3}{ }^{-}$exchange in rabbit, rat, and human duodenum. Gastroenterology 2002, 122, 709-724. [CrossRef] [PubMed]

86. Loo, S.Y.; Chang, M.K.; Chua, C.S.; Kumar, A.P.; Pervaiz, S.; Clement, M.V. NHE-1: A promising target for novel anti-cancer therapeutics. Curr. Pharm. Des. 2012, 18, 1372-1382. [CrossRef] [PubMed]

87. Dong, H.; Sellers, Z.M.; Smith, A.; Chow, J.Y.; Barrett, K.E. $\mathrm{Na}^{+} / \mathrm{Ca}^{2+}$ exchange regulates $\mathrm{Ca}^{2+}$-dependent duodenal mucosal ion transport and $\mathrm{HCO}_{3}{ }^{-}$secretion in mice. Am. J. Physiol. Gastrointest. 2005, 288, G457-G465. [CrossRef] [PubMed]

88. Yoo, B.K.; Yanda, M.K.; No, Y.R.; Yun, C.C. Human intestinal epithelial cell line SK-CO15 is a new model system to study $\mathrm{Na}\left({ }^{+}\right) / \mathrm{H}^{+}$) exchanger 3. Am. J. Physiol. Gastrointest. L. 2012, 303, G180-G188. [CrossRef] [PubMed]

89. Coon, S.; Kekuda, R.; Saha, P.; Sundaram, U. Reciprocal regulation of the primary sodium absorptive pathways in rat intestinal epithelial cells. Am. J. Physiol. Cell. Physiol. 2011, 300, C496-C505. [CrossRef] [PubMed]

90. Hu, Z.; Wang, Y.; Graham, W.V.; Su, L.; Musch, M.W.; Turner, J.R. Mapkapk-2 is a critical signaling intermediate in NHE3 activation following $\mathrm{Na}^{+}$-glucose cotransport. J. Biol. Chem. 2006, 281, 24247-24253. [CrossRef] [PubMed]

91. Zizak, M.; Chen, T.; Bartonicek, D.; Sarker, R.; Zachos, N.C.; Cha, B.; Kovbasnjuk, O.; Korac, J.; Mohan, S.; Cole, R. Calmodulin kinase II constitutively binds, phosphorylates, and inhibits brush border $\mathrm{Na}\left({ }^{+}\right) / \mathrm{H}\left({ }^{+}\right)$ exchanger 3 (NHE3) by a NHERF2 protein-dependent process. J. Biol. Chem. 2012, 287, 13442-13456. [CrossRef] [PubMed]

92. Centeno, V.A.; Díaz de Barboza, G.E.; Marchionatti, A.M.; Alisio, A.E.; Dallorso, M.E.; Nasif, R.; Tolosa de Talamoni, N.G. Dietary calcium deficiency increases $\mathrm{Ca}^{2+}$ uptake and $\mathrm{Ca}^{2+}$ extrusion mechanisms in chick enterocytes. Comp. Biochem. Phys. 2004, 139, 133-141. [CrossRef] [PubMed]

93. Khuituan, P.; Wongdee, K.; Jantarajit, W.; Suntornsaratoon, P.; Krishnamra, N.; Charoenphandhu, N. Fibroblast growth factor-23 negates 1,25(OH)2D3-induced intestinal calcium transport by reducing the transcellular and paracellular calcium fluxes. Arch. Biochem. Biophys. 2013, 536, 46-52. [CrossRef] [PubMed]

94. Ikumi, Y.; Kida, T.; Sakuma, S.; Yamashita, S.; Akashi, M. Polymer-phloridzin conjugates as an anti-diabetic drug that inhibits glucose absorption through the $\mathrm{Na}^{+} /$glucose cotransporter (SGLT1) in the small intestine. J. Control. Release 2008, 125, 42-49. [CrossRef] [PubMed]

(C) 2016 by the authors; licensee MDPI, Basel, Switzerland. This article is an open access article distributed under the terms and conditions of the Creative Commons by Attribution (CC-BY) license (http://creativecommons.org/licenses/by/4.0/). 